\title{
TUBERCULOSIS CONTROL ACTIONS: ANALYSIS BASED ON THE ACCESS AND PRIMARY HEALTH CARE QUALITY IMPROVEMENT PROGRAM
}

\author{
Francisco de Sales Clementino ${ }^{1}$, Emanuella de Castro Marcolino², Luciano Bezerra Gomes ${ }^{3}$, Joria Viana \\ Guerreiro ${ }^{4}$, Francisco Arnoldo Nunes de Miranda ${ }^{5}$
}

\footnotetext{
${ }^{1}$ Ph.D. in Nursing. Professor, Universidade Federal de Campina Grande, Undergraduate Nursing Program. Campina Grande, Paraíba, Brazil. E-mail: fclementino67@yahoo.com.br

${ }^{2}$ M.Sc in Public Health. Nursing, Government of Rio Grande do Norte. Natal, Rio Grande do Norte, Brazil. E-mail: emanuella. de.castro@gmail.com

${ }^{3}$ Doctoral student in Medicine, Universidade Federal do Rio de Janeiro. Professor, Undergraduate Medical Program, Universidade Federal da Paraíba (UFPB). João Pessoa, Paraíba, Brazil. E-mail: lucianobgomes@gmail.com

${ }^{4}$ Ph.D. in Public Health. Professor, Undergraduate Medical Program, UFPB. João Pessoa, Paraíba, Brazil. E-mail: joria2005@yahoo. com.br

${ }_{5}^{5}$ Ph.D. in Nursing. Professor, Undergraduate and Pós-Graduação em Enfermagem, Universidade Federal do Rio Grande do Norte. Natal, Rio Grande do Norte, Brazil. E-mail: farnoldo@gmail.com
}

\begin{abstract}
The study's aim was to analyze primary health care delivered to people with tuberculosis on a national level, based on the information collected by an external assessment implemented by the Programa de Melhoria do Acesso e da Qualidade da Atenção Básica. This cross-sectional study with a quantitative approach used data from the $2^{\text {nd }}$ cycle external assessment of the Programa de Melhoria do Acesso e da Qualidade da Atenção Básica conducted in 2014. The Statistical Package for Social Sciences was used to establish frequencies and check for associations using the Chi-square test. The percentage of Family Health Strategy units recording the annual number of confirmed tuberculosis cases and respiratory symptoms was high for the entire country (81.1\%). In contrast, the recording of follow-up of tuberculosis cases was performed by only $48.3 \%$ of the facilities, while only $48 \%$ of the health basic unites units implemented directly observed treatment. The findings reveal barriers in the structure of health basic unites units regarding the operationalization and sustainability of care provided to individuals with tuberculosis, including directly observed treatment.
\end{abstract}

DESCRIPTORS: Tuberculosis. Health evaluation. Primary health.

\section{AÇÕES DE CONTROLE DA TUBERCULOSE: ANÁLISE A PARTIR DO PROGRAMA DE MELHORIA DO ACESSO E DA QUALIDADE DA ATENÇÃO BÁSICA}

RESUMO: O estudo objetivou analisar as ações de saúde à pessoa com tuberculose na atenção básica à saúde, em nível nacional, a partir da avaliação externa do Programa de Melhoria do Acesso e da Qualidade da Atenção Básica. Trata-se de um estudo transversal de abordagem quantitativa, com base nos dados da avaliação externa do $2^{\circ}$ ciclo do Programa de Melhoria do Acesso e da Qualidade da Atenção Básica realizado em 2014. Utilizou-se o software Statistical Package for Social Sciences para realização de frequências e tentativas de associações por meio do teste estatístico qui-quadrado. Constatou-se que o percentual de registro da estimativa anual do número de casos confirmados de tuberculose e sintomáticos respiratórios na Estratégias Saúde da Família atingiu 81,1\%, em todo Brasil; em contrapartida, o percentual de registros de acompanhamento dos casos de tuberculose alcançou, somente, 48,3\% e tratamento diretamente observado $48 \%$ das unidades básicas de saúde. Os achados indicaram a presença de barreiras na estruturação das unidades básicas de saúde quanto à operacionalização e sustentabilidade da assistência ao portador de tuberculose, incluindo a estratégia do tratamento diretamente observado.

DESCRITORES: Tuberculose. Avaliação em saúde. Atenção primária à saúde. 


\title{
ACCIONES DE CONTROL DE LA TUBERCULOSIS: ANÁLISIS A PARTIR DEL PROGRAMA DE MEJORÍA DEL ACCESO Y DE LA CALIDAD DE LA ATENCIÓN BÁSICA
}

\begin{abstract}
RESUMEN: El estudio tuvo como objetivo analizar las acciones de salud a la persona con tuberculosis en la Atención Básica, a nivel nacional, desde la Evaluación Externa del Programa de Melhoria do Acesso e da Qualidade da Atenção Básica. Se trata de un estudio transversal con abordaje cuantitativo, basados en los datos de la evaluación externa del $2^{\circ}$ ciclo del Programa de Melhoria do Acesso e da Qualidade da Atenção Básica realizado en el año de 2014. Se utilizó el programa software Statistical Package for Social Sciences para la realización de frecuencias y tentativas de asociaciones por medio del teste estadístico Qui-Cuadrado. Se encontró que el porcentual de registro de la estimativa anual del número de casos confirmados de tuberculosis y sintomáticos respiratorios en las ESF atingió 81,1\%, en todo Brasil; en contrapartida el porcentual de registros de acompañamiento de los casos de Tuberculosis alcanzó, solamente, 48,3\% y el Tratamiento Directamente Observado en el $48 \%$ de las unidades básicas de salud. Los datos indicaron la presencia de barreras en la estructuración de las unidades básicas de salud cuanto a la operacionalización y sustentabilidad de la asistencia al portador de tuberculosis, incluyendo la estrategia Tratamiento Directamente Observado.
\end{abstract}

DESCRIPTORES: Tuberculosis. Evaluación en salud. Atención primaria a la salud.

\section{INTRODUCTION}

Tuberculosis (TB) still remains a challenge in the Brazilian public health. Even though the incidence of the disease has decreased approximately $20.3 \%$ since $2003,71,230$ new cases were identified in 2013, of these 11,500 of which were involved in retreatment, with an incidence of 37.2/100,000 inhabitants. TB is the most lethal contagious infectious disease worldwide. It affects all age groups and is aggravated by poor social and economic conditions. ${ }^{1-2}$

Given this epidemiological situation, the World Health Organization (WHO) recommends a Post2015 Proposition, the purpose of which is to eliminate the worldwide TB epidemic, with goals to be achieved by 2025 and 2035. The goals for 2025 include decreasing the mortality rate by $75 \%$ as recorded in 2015 and decreasing its incidence by $50 \%$ worldwide. For 2035, the goals include decreasing mortality rate recorded in 2015 by $95 \%$ and decreasing its incidence by $90 \%$ (to less than $10 / 100,000$ inhabitants). ${ }^{1}$

Considered a priority for the Brazilian government, the disease has been listed in the main national pacts since 2003: Pacto pela Saúde [Health Pact]; Programa Mais Saúde [More Health Program]; Programação das Ações de Vigilância em Saúde [Health Surveillance Actions Programing]; Pacto da Atenção Básica [Primary Healthcare Pact]; and more recently, it lists in the Agenda Estratégica da Secretaria de Vigilância em Saúde [Strategic Agenda of the Health Surveillance Department]. ${ }^{3}$

The strategies considered a priority by the Programa Nacioanl de Controle da Tuberculose (National Tuberculosis Control Program-PNCT) include: improved case-detection rates in the various socioeconomic and clinical epidemiological contexts by strengthening primary healthcare (PHC) services, ${ }^{4}$ without overlooking the importance of the Estratégia Saúde da Família (Family Health Strategy- ESF) in implementing surveillance, prevention and disease control actions. ${ }^{4}$

Despite the numerous advancements obtained in the PHC expansion process, researchers ${ }^{5-7}$ indicate that promoting access for individuals with TB did not facilitate diagnosis in health basic units (HBUs) because of organizational, economic and geographic difficulties faced by the cities in integrating TB control actions.

The decentralization of health actions is a complex issue involving a political-managerial dimension, the qualification of professionals, intersectorial actions, financing of actions, ordination of the information system, and organization of the referral/counter-referral flow for exams supporting diagnosis and specialties, which requires the context of a health care network. ${ }^{8}$

With the implementation of the Programa de melhoria do acesso da qualidade da atenção básica (Access and PHC Quality Improvement Program-PMAQAB) since 2013, the Ministry of Health intends to strengthen PHC actions mainly to expand access to and quality of PHC services, to ensure government actions are effective and to reorganize the healthcare model. ${ }^{9}$

Considering the national nature of the PMAQ$A B$, this study is relevant because it assesses aspects of a national dimension regarding healthcare delivered to individuals with TB within the PHC context. The study's aim was to analyze care provided nationally to individuals with TB at the PHC level based on an external assessment performed by the PMAQ-AB.

\section{METHOD}

This cross-sectional study, with quantitative approach, is based on data collected by the $2^{\text {nd }}$ cycle external assessment conducted by the PMAQ-AB in 
2014, which addressed aspects concerning physical structure and ambivalence, work process, and patient satisfaction.

All the HBUs that adhered to the $1^{\text {st }}$ stage of the program (contractual arrangements for ESF and managers with the PMAQ-AB) participated in the external assessment. In the $2^{\text {nd }}$ cycle of the PMAQ$\mathrm{AB}, 100 \%$ of these units in Brazil were able to adhere to the Program, hence, 24,055 HBUs in the entire country participated in the external assessment.

The instruments developed and revised by the public higher education institutions linked to the Ministry of Health, named Modules I, II, III, IV, V and VI, were used to collect data.

The thematic axes concerning care delivered to individuals with Tuberculosis (Module II) and identification of healthcare units and transportation (Module I) were addressed in this study. The instruments were applied between January and June 2014 by supervisors and field evaluators distributed throughout the entire country.

The logistics used for the application of instruments were as follows: first, city managers of the health sector were contacted by telephone to arrange a visit for the field team. Next, letters were sent to communicate the time, place, and names of the supervisor and quality evaluator who would apply the instruments, in addition to a list of supporting documents to be presented during the interview with the health worker.

Variables concerning care delivered to individuals with TB were: estimated annual number of TB cases and respiratory symptoms; whether the first sputum sample used to diagnose TB was collected in the first consultation; recording of the number of patients with TB in the last year; recording of follow-up of cases; TB reporting forms available at the unit; directly observed treatment (DOT); active search for patients who missed their DOT; surveillance of household contact with new TB cases. All the answers were categorized either as yes, no, or I do not know or did not answer. In regard to the variables concerning identification of HBUs, the type of health unit and availability of a vehicle in good condition were used. Based on the conception of the HBUs, units are responsible for providing programed or unprogramed PHC and integral care in primary specialties to the population, possibly also providing dental care and other types of care provided by professionals with a college degree. ${ }^{9}$

The Statistical Package for the Social Sciences (SPSS), version 21, was used to obtain absolute and relative frequencies of variables and associations using Chi-square. The study was approved by Ethics Committee at the Universidade Federal do Rio Grande do Sul (report No. 21904).

\section{RESULTS}

HBUs predominated among the health facilities participating in the PMAQ-AB's $2^{\text {nd }}$ cycle. This program focuses on the first level of healthcare through other types of health facilities, adapted to the PHC modality, such as: policlinics, mixed healthcare units, and health centers, can also participate.

Of these units, $92.4 \%$ were equipped for oral health, that is, with PHC teams organized differently from those within ESF, though they followed minimum parameters adhering to the PMAQ-AB. Additionally, minimum number of professionals and minimum workload for the workers composing these teams are considered, ${ }^{9}$ however, only $65.9 \%$ of the health units had ESF with oral health, considering the aforementioned minimum parameters in the PHC team (Table 1).

With regard to the information system used in the health units, the (Sistema de Informações da Atenção Básica - PHC Information System SIAB) still predominates and the e-SUS was implemented in only $8.1 \%$ of the health facilities (Table 1 ).

Table 1- Characterization of the health facilities participating in the Programa de Melhoria do Acesso e da Qualdade da Atenção Básica

\begin{tabular}{llrr}
\hline \multicolumn{1}{c}{ Characterization } & \multirow{2}{*}{ Type } & \multicolumn{2}{c}{ Brazil } \\
\cline { 3 - 4 } Type of health unit & & n & $\mathbf{\%}$ \\
& Health center & 2,340 & 9.7 \\
& Health basic unites & 20,571 & 85.5 \\
\hline \multirow{2}{*}{ Total } & Other & 1,144 & 4.8 \\
\hline \multirow{2}{*}{ Equipped with oral health } & Yes & $\mathbf{2 4 , 0 5 5}$ & $\mathbf{1 0 0}$ \\
& No & 1,818 & 7.6 \\
& & 22,237 & 92.4 \\
\hline
\end{tabular}




\begin{tabular}{llrr}
\hline Total & & $\mathbf{2 4 , 0 5 5}$ & $\mathbf{1 0 0}$ \\
\hline \multirow{2}{*}{ Oral health } & Family health strategy teams w/ oral health & 15,854 & 65.9 \\
& Family health strategy teams w/o oral health & 8,201 & 34.1 \\
\hline Total & & $\mathbf{2 4 , 0 5 5}$ & $\mathbf{1 0 0}$ \\
\hline \multirow{3}{*}{ Information system } & Primary healthcare information system & 20,354 & 84.6 \\
& e-SUS & 1,940 & 8.1 \\
& Others & 1,215 & 5.1 \\
& Did not know/did not answer & 546 & 2.3 \\
\hline Total & & $\mathbf{2 4 , 0 5 5}$ & $\mathbf{1 0 0}$ \\
\hline
\end{tabular}

Care provided by the HBUs to individuals with TB per region is presented in Table 2 . The percentage of $\mathrm{PHC}$ units recording the annual number of confirmed TB cases and respiratory symptoms was high for the entire country $(81.1 \%)$.

The first sputum sample was collected in the first consultation to establish a TB diagnosis by $51.5 \%$ of the HBUs in the northeast and by $62.9 \%$ of HBUs, at the most, in the south. The number of patients with TB in the most recent year, with documentary evidence, was presented by $51 \%$ of all the HBUs in Brazil; $43.6 \%$ of the teams did not present patients with TB in the territory under their coverage. The percentages followed the same pattern per region (Table 2).

With regard to follow-up of TB cases under the responsibility of HBUs, $49 \%$ of these units did not know or did not answer this question. The north presented the highest percentage of follow-up of TB cases $(54.1 \%)$, while the south presented the lowest percentage $(46.4 \%)$.

TB reporting forms were found in $89.4 \%$ of the HBUs under study; the percentages followed the same pattern per region. The northeast presented the highest percentage of reporting forms (92.8\%) (Table 2).

DOT has been performed in $48 \%$ of the Brazil- ian HBUs, a percentage similar to that of units that did not know or did not answer this item (43.6\%). The northeast presented the highest number of HBUs that did not know or did not answer concerning DOT $(45.1 \%)$, while the north presented the lowest number of units that did not know or did not answer this item (35.6\%). The active search for individuals missing DOT across the country followed the same percentage pattern, with $44.8 \%$ of the HBUs reported actively searching for patients, while $49 \%$ reported a lack of knowledge or did not answer the question. With regard to this item, the percentage of HBUs that did not know or did not answer whether the unit actively searched for patients is higher in all regions than the percentage of HBUs that do search for patients missing treatment (Table 2).

A larger percentage of HBUs did not know or did not answer the question regarding investigation of household contact with new TB cases, when compared to those units that investigate household contact with TB cases; the mid-west region stands out with $50.5 \%$ of the HBUs being unable to report whether they perform this action, compared to $47.7 \%$ of HBUs that do investigate household contact with new TB cases in the territory under their coverage (Table 3).

Table 2 - Care delivered to people with tuberculosis in the PHC units participating in the primary health care quality improvement program $2^{\text {nd }}$ cycle per region, Brazil, 2014

\begin{tabular}{|c|c|c|c|c|c|c|c|c|c|c|c|c|c|c|c|c|c|c|}
\hline \multirow{2}{*}{$\begin{array}{l}\text { Primary Healthcare Units } \\
\text { that... }\end{array}$} & \multicolumn{3}{|c|}{ Brazil } & \multicolumn{9}{|c|}{ North } & \multicolumn{3}{|c|}{ Southeast } & \multicolumn{3}{|c|}{ South } \\
\hline & $\begin{array}{c}\text { Yes } \\
\%\end{array}$ & $\begin{array}{c}\text { No } \\
\%\end{array}$ & $\begin{array}{c}\text { DNK}^{*} \\
\%\end{array}$ & $\begin{array}{c}\text { Yes } \\
\%\end{array}$ & $\begin{array}{c}\text { No } \\
\%\end{array}$ & $\begin{array}{c}\text { DNK }^{*} \\
\%\end{array}$ & $\begin{array}{c}\text { Yes } \\
\%\end{array}$ & $\begin{array}{c}\text { No } \\
\%\end{array}$ & $\begin{array}{c}\text { DNK }^{*} \\
\%\end{array}$ & $\begin{array}{c}\text { Yes } \\
\%\end{array}$ & $\begin{array}{c}\text { No } \\
\%\end{array}$ & $\begin{array}{c}\text { DNK }^{*} \\
\%\end{array}$ & $\begin{array}{c}\text { Yes } \\
\%\end{array}$ & $\begin{array}{c}\text { No } \\
\%\end{array}$ & $\begin{array}{c}\text { DNK }^{*} \\
\%\end{array}$ & $\begin{array}{c}\text { Yes } \\
\%\end{array}$ & $\begin{array}{c}\text { No } \\
\%\end{array}$ & $\begin{array}{c}\text { DNK }^{*} \\
\%\end{array}$ \\
\hline $\begin{array}{l}\text { Present an annual estimate } \\
\text { of number of TB cases and } \\
\text { respiratory symptoms }\end{array}$ & 81.1 & 18.9 & - & 79.6 & 20.4 & - & 76.0 & 24.0 & - & 79.5 & 20.5 & - & 83.8 & 16.2 & - & 81.8 & 18.2 & - \\
\hline $\begin{array}{l}\text { Collect the } 1^{\text {st }} \text { sputum sample } \\
\text { to diagnose TB in the } 1^{\text {st }} \text { con- } \\
\text { sultation }\end{array}$ & 57.0 & 43.0 & - & 51.5 & 48.5 & - & 44.5 & 55.5 & - & 64.7 & 35.3 & - & 60.9 & 39.1 & - & 62.9 & 37.1 & - \\
\hline $\begin{array}{l}\text { Present recording of the } \\
\text { number of individuals with } \\
\text { TB in the last year }\end{array}$ & 51.0 & 5.4 & $43.6 \dagger$ & 50.8 & 4.1 & $45.1 \dagger$ & 55.8 & 8.6 & $35.6 \dagger$ & 49.5 & 6.9 & $43.6 \dagger$ & 50.5 & 5.4 & $44.1 \dagger$ & 50.2 & 6.0 & 43.8 \\
\hline
\end{tabular}




\begin{tabular}{|c|c|c|c|c|c|c|c|c|c|c|c|c|c|c|c|c|c|c|}
\hline \multirow{2}{*}{$\begin{array}{l}\text { Primary Healthcare Units } \\
\text { that... }\end{array}$} & \multicolumn{3}{|c|}{ Brazil } & \multicolumn{9}{|c|}{ North } & \multicolumn{3}{|c|}{ Southeast } & \multicolumn{3}{|c|}{ South } \\
\hline & $\begin{array}{c}\text { Yes } \\
\%\end{array}$ & $\begin{array}{l}\text { No } \\
\%\end{array}$ & $\begin{array}{c}\text { DNK }^{*} \\
\%\end{array}$ & $\begin{array}{c}\text { Yes } \\
\%\end{array}$ & $\begin{array}{c}\text { No } \\
\%\end{array}$ & $\begin{array}{c}\text { DNK* }^{*} \\
\%\end{array}$ & $\begin{array}{c}\text { Yes } \\
\%\end{array}$ & $\begin{array}{c}\text { No } \\
\%\end{array}$ & $\begin{array}{c}\text { DNK }^{*} \\
\%\end{array}$ & $\begin{array}{c}\text { Yes } \\
\%\end{array}$ & $\begin{array}{c}\text { No } \\
\%\end{array}$ & $\begin{array}{c}\mathrm{DNK}^{*} \\
\%\end{array}$ & $\begin{array}{c}\text { Yes } \\
\%\end{array}$ & $\begin{array}{l}\text { No } \\
\%\end{array}$ & $\begin{array}{c}\text { DNK* }^{*} \\
\%\end{array}$ & $\begin{array}{c}\text { Yes } \\
\%\end{array}$ & $\begin{array}{l}\text { No } \\
\%\end{array}$ & $\begin{array}{c}\text { DNK* }^{*} \\
\%\end{array}$ \\
\hline $\begin{array}{l}\text { Present a record of follow-1 } \\
\text { of cases }\end{array}$ & 48.3 & 2.7 & 49.0 & 48.8 & 2.0 & 49.2 & 54.1 & 1.7 & 44.2 & 47.4 & 2.1 & 50.5 & 47.2 & 3.3 & 49.5 & 46.4 & 3.9 & 49.8 \\
\hline TB reporting forms in & 89.4 & 10.6 & - & 92.8 & 7.2 & - & 87.6 & 12.4 & - & 87.4 & 12.6 & - & 87.6 & 12.4 & - & 86.9 & 13.1 & - \\
\hline Perform DOT & 48.0 & 8.4 & 43.6 & 46.9 & 8.0 & 45.1 & 53.2 & 11.3 & 35.6 & 49.2 & 7.2 & 43.6 & 47.9 & 8.0 & 44.1 & 46.6 & 9.7 & 43.8 \\
\hline $\begin{array}{l}\text { Actively search for patients } \\
\text { missing DOT }\end{array}$ & 44.8 & 6.3 & 49.0 & 43.8 & 7.0 & 49.2 & 48.9 & 7.1 & 44.0 & 45.3 & 4.3 & 50.4 & 44.5 & 6.0 & 49.5 & 44.4 & 5.9 & 49.8 \\
\hline $\begin{array}{l}\text { Watch for household contact } \\
\text { with new TB cases }\end{array}$ & 48.8 & 2.2 & 49.0 & 49.0 & 1.8 & 49.2 & 53.8 & 2.0 & 44.2 & 47.7 & 1.8 & 50.5 & 48.3 & 2.2 & 49.5 & 46.6 & 3.6 & 49.8 \\
\hline
\end{tabular}

Table 3 - Association between care actions delivered to individuals with tuberculosis and availability of transportation in PHC units participating in primary health care quality improvement program $2^{\text {nd }}$ cycle, Brazil, 2014

\begin{tabular}{|c|c|c|c|c|c|c|c|}
\hline \multirow{3}{*}{ Care actions } & & \multicolumn{6}{|c|}{ Availability in health units of transportation in good condition } \\
\hline & & \multicolumn{2}{|c|}{ Yes } & \multicolumn{2}{|c|}{ No } & \multirow{2}{*}{ p-value } & \multirow{2}{*}{ Prevalence ratio } \\
\hline & & $\mathbf{n}$ & $\%$ & $\mathbf{n}$ & $\%$ & & \\
\hline \multirow{3}{*}{$\begin{array}{l}\text { Investigation of household contact } \\
\text { with new TB cases }\end{array}$} & Yes & 7,212 & 96 & 291 & 97 & 5.50 & $0.390(0.173-$ \\
\hline & No & 291 & 4 & 6 & 3 & & $0.882)$ \\
\hline & Total & 7,503 & 100 & 297 & 100 & & \\
\hline \multirow{3}{*}{ DOT implementation } & Yes & 7,116 & 84 & 285 & 84 & 0.030 & - \\
\hline & No & 1,277 & 16 & 51 & 16 & & \\
\hline & Total & 8,393 & 100 & 336 & 100 & & \\
\hline \multirow{3}{*}{$\begin{array}{l}\text { Active search for patients missing } \\
\text { DOT }\end{array}$} & Yes & 6,623 & 87 & 261 & 87 & 0.134 & $0.936(.656-$ \\
\hline & No & 976 & 13 & 36 & 13 & & $1.335)$ \\
\hline & Total & 7,599 & 100 & 297 & 100 & & \\
\hline
\end{tabular}

Association was found between the variables "Availability of transportation in good condition" and "DOT implementation" $(\mathrm{p}<0.05)$. Association was also found between "Availability of transportation in good condition" and the variables "Investigation of household contact with TB new cases" and "Actively searching for patients missing DOT" ( $p>0.05)$. Note that more than $70 \%$ of the HBUs did not know or did not answer the item regarding the availability of transportation in good condition (Table 3).

\section{DISCUSSION}

This study enabled identifying the challenges routinely faced by the NTCP when addressing people with TB in the five Brazilian regions, considering actions to control the disease as regulated by the Ministry of Health. With regard to the collection of first sputum sample in the first consultation performed by the HBUs to diagnose TB, the results show a mean coverage below $60 \%$ in the five Brazilian regions, while the PNCT recommends this procedure be performed for all symptomatic cases.
One study conducted in Porto Alegre ${ }^{10}$ found a similar percentage regarding sputum smears in PHC. Such a fact was considered a concern because, in addition to its low cost, a sputum smear is the main diagnostic method recommended by the WHO to diagnose pulmonary TB. A late diagnosis is considered the main variable that accounts for the high prevalence of the disease, thus, the capacity of the healthcare network has to be reconsidered in order to it be able to deliver better coordinated care to minimize access barriers and favor timely diagnosis of TB in PHC services. ${ }^{4}$

One study developed in three Brazilian capitals also reports the low frequency with which sputum smear is performed in HBUs. ${ }^{11}$ Likewise, one study conducted in São José do Rio Preto, a priority city for TB control, highlighted that Emergency Service Units were the entrance door for $\mathrm{TB}$ diagnosis $(49.4 \%)$, while hospitals were the facilities that most frequently diagnosed the disease (39.5\%), followed by HBUs $(30.9 \%){ }^{12}$

Other studies ${ }^{10,13-14}$ confirm that TB control actions remain centralized in referral facilities, such 
as Emergency units and hospitals, in which a large number of cases are diagnosed and therapeutic regimes are established, which is contrary to what is recommended by the Ministry of Health, which has reinforced the decentralization of care since the implementation of the NTCP. ${ }^{10}$

The NTCP established two primary strategies in 2013 to cope with TB: expand diagnosis with new technology and strengthen TB actions at the PHC level. Nonetheless, TB diagnosis is usually delayed in Brazil, which is seen when other indicators are considered, such as cure rate, treatment abandonment, mortality, comorbidities, and time elapsed from the appearance of symptoms to the establishment of diagnosis, among others..$^{15}$ These incompatibilities relate to follow-up that is focused on medication therapy, disregarding socioeconomic and cultural complexities, which influence one's perceptions, from the onset of the disease up to treatment adherence. From the perspective of integrality, this reveals weakness in a care delivery model developed from the perspective of integrality. ${ }^{16}$

One study conducted in 2012 reveals that TB treatment abandonment is related to the social environment to which a patient belongs. ${ }^{17}$ Additionally, treatment abandonment also results from poor follow-up. ${ }^{18}$

Therefore, to fully provide access, diagnosis and TB treatment to patients, it is necessary to transfer essential care actions to PHC services, properly structuring HBUs in clinical-scientific, structural and organizational terms so that they are able to properly deal with patients and provide integral care. ${ }^{13}$

Regarding the number of individuals with $\mathrm{TB}$ in the last year, the results reveal a concerning epidemiological situation among the HBUs under study, considering that $43.6 \%$ of these did not keep a record of patients with TB in their area of coverage.

Therefore, management should invest in professional training, seeking to improve and reorganize the work process with changes in the practice from the perspective of the Politica nacional de Educação Permanente em Saúde (National Policy of Permanent Health Education-EPS) involving four pillars: education, management, care delivery and social control, adopting as its methodology the problematization of the work process in the healthcare networks of the Brazilian Public Health System. ${ }^{19}$ Additionally, it is relevant to clarify knowledge concerning the topic, as the results available contribute to decision-making and to the development of policies to control TB. ${ }^{20}$
In addition to complete reporting forms concerning cases in which TB is diagnosed, completing the Treatment Control Book, an instrument used to record data concerning the follow-up of TB patients (result of exams, criterion for discharge), is also recommended. Information must be sent monthly to the first informatized level of the Sistema de Informação de agravos de notificação (Notifiable Diseases Information System-SINAN). ${ }^{4}$

Brazil has not yet achieved the goals established by the WHO, namely $70 \%$ of cases detected, $85 \%$ cure through DOT, and at most $5 \%$ treatment abandonment. ${ }^{13}$ Thus, the bottlenecks of the TB surveillance system need to be identified to determine at which point patients are not being identified, and consequently not reported, treated or monitored.

Underreporting of cases, mainly due to poor performance of active searches for those who are missing DOT, inefficient recording and information flow, reflect a lack of equal access to healthcare services. Studies conducted in various regions of Brazil highlight potential explanations for these problems, such as: training processes are discontinued, lack of permanent education policies, and high turnover of healthcare workers due to the rotation or discontinuity of ruling political parties..$^{20-22}$

Additionally, attention should be paid to the training of healthcare workers able to meet the requirements of the Brazilian Public Health System and its principles. ${ }^{23}$ Professionals and policies that transcend the fragmented and reductionist nature of actions are essential for the effective control of TB. ${ }^{24}$

The study reveals that supervised treatment has been implemented in $48 \%$ of the HBUs under study, similar to the percentage of health units that did not know or did not answer this item (43.6\%). Note that ESF units are not following the NTCP guidelines in regard to the coverage of patients undergoing DOT, which indicates the need to improve actions in order to enhance the quality of TB treatment as recommended by the WHO.

Since 1993, the WHO has recommended DOT as the main strategy to control the disease, ${ }^{25}$ decreasing the transmission of TB bacilli by implementing early diagnosis and appropriate treatment. ${ }^{26-28}$ DOT is based on four premises: detection of cases through sputum smear for those with respiratory symptoms; treatment through regular supply of medications; recording information regarding the treatment; and government commitment through health policies focusing on TB control. ${ }^{29}$

One of the cornerstones of the DOT strategy is characterized by changing the way medication 
is administered, without changing the therapeutic regimen. That is, a trained worker is responsible for observing the taking of medication by the patient from the beginning of the treatment up to complete cure. ${ }^{25-27}$

In addition to observing the treatment, the workers conform with the logic that an individual with TB is, above all, a human being with demands that need to be perceived and resolved as much as possible. This holistic care is directly reflected in treatment adherence and, consequently, in potential cure. ${ }^{30}$

Because treatment abandonment is crucial when TB treatment fails to materialize, the various and complex aspects associated with this fact need to be highlighted. Such aspects are related both to the patient and to the operationalization of the treatment and the treatment itself. Hence, the relationship developed between professional and patient is a tool that can enhance care practices, self-care and responsibility shared with the individual with TB. ${ }^{31}$

The professional practices of the PHC teams concerning the active search for individuals with TB and DOT implementation, as well as the organizational support of HBUs, are essential to combating TB. This is confirmed by the significant association between variables $(p<0.05)$. There is low coverage of active searches and investigation of household contact with new TB cases due to operational and logistic reasons, among which is lack of transportation for the teams.

This situation implies weaknesses in the DOT operationalization process, suggesting that there is a need for local PHC policies concerning the monitoring of household contact with order to interrupt TB transmission in a timely manner. Additionally, healthcare professionals, as well as health policies, need to overcome the fragmented and reductionist nature of actions, enabling the delivery of integral care to effectively control the disease. ${ }^{31}$

\section{CONCLUSION}

This study's objective was to analyze the care provided to individuals with TB using information collected in the external assessment performed by the PMAQ-AB. The findings indicate barriers in the structuring of HBUs, such as problems of an organizational, geographic and economic nature.

The way PHC is organized is a determining factor in ensuring access to early diagnosis and follow-up of patients and families in the area under coverage, considering the fragilities presented in terms of the operationalization and sustainability of the DOT strategy, such as: a low percentage of HBUs performing DOT; the merely incipient active search for those missing DOT; and the insufficient surveillance of household contact with TB cases, in addition to a high percentage of units lacking knowledge concerning these priority strategies.

The elements concerning PHC delivered to individuals with TB lead us to reflect upon means that are objectively necessary to decentralize actions, moving them to the PHC level, considering evident barriers that prevent the implementation of the NTCP through Brazilian family health teams.

Strengthening the DOT strategy requires an inter-sector commitment, starting with the government ensuring the resources needed to implement TB control and to provide and guarantee that patients and families have access to quality healthcare services.

The PMAQ-AB's external assessment enabled a systematic analysis of the Brazilian PHC context and revealed the weaknesses of the NTCP concerning the practice of family health teams. Thus, it provided an opportunity to re-think how to decentralize care delivered to individuals with TB at the first level of care.

Therefore, there is a need to reorient actions, change inter-sector and inter-government approaches, and enhance PHC through organizational models that encourage healthcare workers to produce the essence of PHC, namely: establishment of bonds; health surveillance and care delivery over time; and, more importantly, assume TB control as a priority action in the areas under the units' coverage.

\section{REFERENCES}

1. World Health Organization (WHO). Global Tuberculosis report 2013. Geneva $(\mathrm{CH})$ : WHO Library; 2013.

2. Sá LD, Rodrigues DC, Barreto AJ, Oliveira AA, Pinheiro PG, Nogueira JA. A organização da estratégia saúde da família e aspectos relacionados ao atraso do diagnóstico da tuberculose. Cogitare Enferm [Internet] 2011 [cited 2015 Jul 15]; 16(3):437-42. Available from: http://ojs.c3sl.ufpr.br/ojs/index.php/cogitare/ article/view/21245/16227

3. Ministério da Saúde (BR). Boletim epidemiológico. Coordenação-Geral do Programa Nacional de Controle da Tuberculose. Departamento de Vigilância de Doenças Transmissíveis - DEVIT. Secretaria de Vigilância em Saúde. Tuberculose no Brasil: realidade e perspectivas. Brasília (DF): MS; 2012.

4. Paiva RCG, Nogueira JÁ, Sá LD, Nóbrega RG, Trigueiro DRSG, Villa TCSV. Acessibilidade ao 
diagnóstico de tuberculose em município do Nordeste do Brasil: desafio da atenção básica. Rev Eletr Enf [Internet]. 2014 [cited 2016 Feb 12]; 16(3):520-6. Available from: http://dx.doi.org/10.5216/ree. v16i3.23491

5. Clementino FS, Miranda FAN. Tuberculose: acolhimento e informação na perspectiva da visita domiciliária. Rev Enferm UERJ [Internet]. 2015 [cited 2016 Feb 12]; 23(3):350-4 Available from: http:/ / www.e-publicacoes.uerj.br/index.php/ enfermagemuerj/article/view/4289/13773

6. Villa TCS, Ponce MAZ, Wysock AD, Andrade RLP, Arakawa T, Scatolin BE, et al. Diagnóstico oportuno da tuberculose nos serviços de saúde de diversas regiões do Brasil. Rev Latino-Am Enfermagem [Internet] 2013 [cited 2016 Feb 10]; 21(Spec):[08 telas]. Available from: http://www.scielo.br/pdf/rlae/v21nspe/pt_24.pdf

7. Bertolozzi MR, Takahashi RF, Hino P, Litvoc M, França FOS. O controle da tuberculose: um desafio para a saúde pública. Rev Med (São Paulo) [Internet]. 2014 [cited 2015 Jul 11]; 93(2):83-9. Available from: http:/ / www.revistas.usp.br/revistadc/article/view/97330

8. Mota RRA, David HMSL. Programa Nacional de Melhoria do Acesso e da Qualidade da Atenção Básica: questões a problematizar. Rev Enferm UERJ [Internet]. 2015 [cited 2015 Jun 10]; 23(1):122-7. Available from: http:/ / www.facenf.uerj.br/v23n1/v23n1a20.pdf

9. Ministério da Saúde (BR). Secretaria de Atenção a Saúde. Departamento de Atenção Básica. Manual do Avaliador da Qualidade. Brasília (BR): MS; 2013.

10. Almeida CPB, Skupien EC, Silva DR. Health care seeking behavior and patient delay in tuberculosis diagnosis. Cad Saúde Pública [Internet]. 2015 [cited 2015 jul 10]; 31(2):321-30. Available from: http:/ / www.scielosp.org/pdf/csp/v31n2/0102-311Xcsp-31-02-00321.pdf

11. Campos CEA, Fonseca ACF, Pessini ML. Análise dos percursos assistenciais de pacientes com tuberculose por equipes de saúde em três capitais brasileiras. Que lições os profissionais podem tirar? Cad Saúde Colet [Internet]. 2012 [cited 2015 Jul 23]; 20(2):188-94. Available from: http://www.iesc.ufrj.br/cadernos/ images/csc/2012_2/artigos/csc_v20n2_188-194.pdf

12. Ponce MAS, Wysocki AD, Scatolin BE, Andrade RLP, Arakawa T, Netto AR et al. Diagnóstico da tuberculose: desempenho do primeiro serviço de saúde procurado em São José do Rio Preto, São Paulo, Brasil. Cad Saúde Pública [Internet]. 2013 [cited 2015 Jul 02]; 29(5):945-54. Available from: http:// www.scielo.br/scielo.php?pid=S0102311X2013000500012\&script=sci_arttext

13. Souza MSPL, Aquino R, Pereira SM, Costa MCN, Barreto ML, Natividade $\mathrm{M}$ et al. Fatores associados ao acesso geográfico aos serviços de saúde por pessoas com tuberculose em três capitais do Nordeste brasileiro. Cad Saúde Pública [Internet]. 2015 [cited 2015 Jul 13]; 31(1):111-20. Available from: http:/ /
www.scielosp.org/pdf/csp/v31n1/0102-311Xcsp-31-01-00111.pdf

14. Amaral AS, Tamaki EM, Sales CM, Renovato RD. Avaliação da descentralização do programa de controle da tuberculose do nível secundário para o nível primário do sistema de saúde de DouradosMS. Saúde Soc [Internet]. 2010 [cited 2015 Jun 23]; 19(4):794-802. Available from: http://www.scielo. br/pdf/sausoc/v19n4/07.pdf

15. Souza KMJ, Sá LD, Silva LMC, Palha PF. Atuação da Enfermagem na transferência da política do tratamento diretamente observado da tuberculose. Rev Esc Enferm USP [Internet]. 2014 [cited 2015 May 01]; 48(5):874-82. Available from: http:// www.scielo.br/pdf/reeusp/v48n5/pt_0080-6234reeusp-48-05-874.pdf

16. Sá LD, Scatena LM, Rodrigues RAP, Nogueira JA, Silva AO, Villa TCS. Gateway to the diagnosis of tuberculosis among elders in Brazilian municipalities. Rev Bras Enferm [Internet]. 2015 [cited 2016 Feb 11]; 68(3):408-14. Available from: http:/ / www.scielo.br/ pdf/reben/v68n3/0034-7167-reben-68-03-0467.pdf

17. Souza ABF, Cruz ZV. Abandono do tratamento da tuberculose no município de Itapetinga-BA: um estudo da influência dos fatores ambientais. Encic Biosfera. [Internet]. 2012 [cited 2016 Feb 08]; 8(14):1471-86. Available from: http:/ / www.conhecer. org.br/enciclop/2012a/saude/abandono.pdf

18. Santos TMMG, Nogueira LT, Santos, Santos LNM, Costa CM. O acesso ao diagnóstico e ao tratamento de tuberculose em uma capital do nordeste brasileiro. Rev Enferm UERJ. 2012; 20(3):300-5.

19. Oliveira RCC, Adário KDO, Sá LD, Videres ARN, Souza SAF, Pinheiro PGOD. Speeches of managers about the policy of the directly observed treatment for tuberculosis. Texto Contexto Enferm [Internet]. 2016; [cited 2016 Sep 27] 25(2):e3210015 Available from: http:/ / www.scielo.br/pdf/tce/v25n2/pt_0104-0707tce-25-02-3210015.pdf

20. Lima LM, Harterb J, Tomberg JO, Vieira DA, Antunes ML, Cardozo-Gonzalese RI. Avaliação do acompanhamento e desfecho de casos de tuberculose em município do sul do Brasil. Rev Gaúcha Enferm [Internet]. 2016; [cited 2016 Sep 27] 37(1):e51467 Available from: http://www.scielo.br/pdf/rgenf/v37n1/01026933-rgenf-37-1-1983-144720160151467.pdf

21. Cardoso GCP, Cruz MM, Abreu DMF, Decotelli PV, Chrispim PPM, Borenstein JS et al. A conformidade das ações do tratamento diretamente observado para tuberculose na perspectiva dos profissionais de duas unidades de saúde da cidade do Rio de Janeiro. Cad Saúde Colet [Internet]. 2012 [cited 2015 Jun 22]; 20(2):203-10. Available from: http:/ / www.cadernos. iesc.ufrj.br/cadernos/images/csc/2012_2/artigos/ csc_v20n2_203-210.pdf

22. Cunha NV, Cavalcanti MLT, Costa AJL. Diagnóstico situacional da descentralização do controle da 
tuberculose para a Estratégia Saúde da Família em Jardim Catarina - São Gonçalo (RJ), 2010. Cad Saúde Colet [Internet]. 2012 [cited 2015 Jul 05]; 20(2):17787. Available from: http://www.cadernos.iesc. ufrj.br/cadernos/images/csc/2012_2/artigos/ csc_v20n2_177-187.pdf

23. Grecco R, Oliveira CBB; Silva LMC; Souza KMJ; Santos GP; Palha PF. Tratamento diretamente observado da tuberculose: processos de aprendizagem em uma instituição de ensino superior. Rev Enferm UERJ [Internet]. 2014 [cited 2016 Feb 10]; 22(1):77-82. Available from: http://www.facenf.uerj.br/v22n1/ v22n1a12.pdf

24. Silva DM. Tratamento da tuberculose na Atenção Básica: avaliação de estrutura e processo dos serviços de saúde [dissertação]. João Pessoa (PB): Universidade Federal da Paraíba, Programa de Pós-graduação em Enfermagem; 2013.

25. World Health Organization (WHO). Global Tuberculosis Control: epidemiology, strategy, financing: WHO report 2011. Geneva: WHO; 2011.

26. Ministério da Saúde (BR). Secretaria de Vigilância em Saúde. Programa Nacional de Controle da Tuberculose. Manual de Recomendações para o Controle da Tuberculose no Brasil. Brasília (DF): MS; 2011.

27. Ministério da Saúde (BR). Secretaria de Vigilância em Saúde. Departamento de Vigilância Epidemiológica.
Programa Nacional de Controle da Tuberculose. Brasília (DF): MS; 2011.

28. Siqueira HR, Vargas TC, Costa W, Faria AC, Lopes AJ, Capone D. O tratamento atual da tuberculose (para adolescentes e adultos) comentado. Rev HUPE [Internet]. 2010 [cited 2015 Jul 13]; 9. Available from: http://www.e-publicacoes.uerj.br/index.php/ revistahupe/article/view/9178

29. Sá LD, Oliveira AAV, Gomes ALC, Nogueira JA,Villa TCS, Collet S. Caring for tuberculosis patients in the Family Health Strategy: the nurses' perceptions. Rev Esc Enferm USP [Internet]. 2012 [cited 2015 Jun 20]; 46(2):356-63. Available from: http:/ / www.scielo.br/scielo.php?pid=s008062342012000200013\&script=sci_arttext\&tlng $=$ en

30. Hino P, Takahashi RF, Bertolozzi MR, Villa TCS, Egry EY. Conhecimento da equipe de saúde da família acerca das necessidades de saúde das pessoas com tuberculose. Rev Latino-Am Enferm [Internet]. 2012 [cited 2016 Feb 15]; 20(1):44-51 Available from: http:/ / www.scielo.br/pdf/rlae/v20n1/pt_07.pdf

31. Silva PF, Moura GS, Caldas AJM. Fatores associados ao abandono do tratamento da tuberculose pulmonar no Maranhão, Brasil, no período de 2001 a 2010. Cad Saúde Pública [Internet]. 2014 [cited 2015 Jul 15]; 30(8):1745-54. Available from: http:/ / www.scielo.br/scielo.php?pi$\mathrm{d}=$ S0102-311 X2014000801745\&script $=$ sci_arttext 